\title{
前立腺肥大と膀胱頸部
}

$\begin{array}{ccccc} & \text { 水 } & \text { 本 } & \text { 龍 } & \text { 助 } \\ & \text { 並 } & \text { 河 } & \text { 広 } & \text { 二 } \\ \text { 日本大学医学部泌尿器科教室 } & \text { 西 } & \text { 村 } & \text { 邦 } & \text { 康 } \\ \text { (主任: 永田正教授) } & \text { 三 } & \text { 宅 } & \text { 則 } & \text { 保 } \\ & \text { 柴 } & \text { 田 } & & \text { 昭 }\end{array}$

\section{BENIGN HYPERTROPHY OF THE PROSTATE AND NECK OF THE BLADDER}

\author{
Ryusuke Mizumoto, Kōji Namikawa, \\ Kuniyasu Nisimura, Noriyasu Miyake, Akira Sibata \\ Department of Urology, Nihon University School of Medicine
}

(Director : Prof. M. Nagata)

\section{I. 緒 言}

膀胼頸部から後部尿道にかけての尿路閉塞性疾患につ いては，欧米にては古くから前立腺々腫との関連，扰よ び小児泌尿器疾患の重要部を占め 頻度も高い小児の膀 胱頸部疾患との関連に於て重視されて来た。

わが国でも前立腺々腫の手術が全国どてででも行なえ るようになったととど，最近の急速な小児泌尿器科へ の関心 ${ }^{22 \sim 8)}$ と共に，膀胱頸部疾患が重視されるようにな って来た。

膀胱顓部, 後部尿道に於ける閉塞性疾患の名称, 分類 に就ても古くから多くの報告者により種々探究されてい

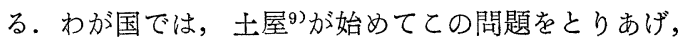
以来多くの人々により報告されている，土屋 ${ }^{10)}$ は，最近 でも豊富な自験例加ら詳細な検討を行なっている。

われわれがとこでとりあげようとしているのは，膀胱 頸部矤患のうち, 所謂idiopathic bladder neck contractur と呼ばれるもので, Sphinktersklerose, Prostatisme sans prostate, Annulussklerose, Hyperplasie musculaire, 狭義つMedian bar 等と呼ばれているものである.

最近 1 年半の閒に (昭和 37 年 4 月より昭和 38 年 10 月迄) 日本大学泌尿器科教室に於て, 頸部硬化症と診断, 手術 したものは23例，同期間中に前立腺肥大症の手術を58例 行なって居り，両者の比はほぼ $3 ; 7$ となる.

この idiopathic bladder neck contractur の entity を究明するに当り，問題となるのは膀胱頸部，殊に内括
筋部の topography が未だ一致した見解に達していな いととである，そとでわれわれは剖検材料で膀胱頸部が 正常と考元られるものの肉眼的, 組織学的検索を行な い，手術的に摘出した前立腺抽よび膀耖頸部の肉眼的， 組織学的所見とをそれぞれ比較検索した。手術摘出材料 は全て40才以上のものである.

\section{II. 検索材料，方法およびその成續}

A) 肉眼的検索

a)材料：最近 3 力月以内に剖検したもので生前泌尿器 科的疾患がなく, 剖検時にも泌尿器科的病変の認められ なかった男子 21 才，28才，33才，37才，62才，69才， 78 才, 83 才の計 8 例の前立腺を附したままの膀胱と最近 1.5 年間に 前立腺肥大症として手術したものの内，前立 腺々腫全体を en block として摘出した新鮮材料 21 例を 用いた。

b)方法扔よび成績

i)剖検例：前立腺を附したままの膀胱を 尿管口より約 $1 \mathrm{~cm}$ の後方の部で尿道長軸に直角に垂直断し, 前立腺 は, 前立腺尖部で同様に垂直断し, 又精管は膨大部で切 断して検索に供した。検索には肉眼又はルーペで見なが ら小摄子又は小尖刃を用いて筋束を追求した。

1） 40 才以下の 4 例 : 膀胱粘膜を内尿道口の方向に剥 離して行くと容易に粘膜下層から遊離するととが出来， 内尿道口を越えて尿道粘膜に移行して居り, 更にての尿 道粘膜は縦に精皁の方へ容易に剝離された。次に膀胱内 
縦走筋の豩離にかかると三角部を除く他の部では，剝離 比較的容易で, 筋束は直線状, 輪状又は $\mathrm{S}$ 字状の走向を とって尿道粘膜下層で尿道内腔を輪状に配列して下行し て行く，三角部では筋束は甚だ密となり，個々の筋束と しては剥離出来ず，又，下層と囲く附着している。乙れ を周辺から下層の筋束の走向を参照しつつ鋭的に切除し て行くと内尿道口後縁では著しく減少して数条の細い筋 束となって内尿道口を下行して行く.

結局，内縦走筋は，尿道内腔を輪状にとり囲てんで尿 道の筋肉に移行している.

次に膀胱の外表面を包んでいる統合織と筋膜を膀胱筋 層を損傷しないようにとり除くと，外䋛走筋が現われて くる. 乙の外縱走筋は膀胱の切断端附近では, 深浅両層 が認められ，中輸筋との区別がやや困難であったが，膀 胱頸部の両側面では，乙の深浅雨層は 1 つの筋束となっ て, 中輪筋とは容易に識別出来, 剝離するてとが出来た． てれを尿道の方向に剝離して行くと, 膀胱頸部腹側から 背側㲸汃け前立腺の外表面に向い，尿道の縦走内層筋 層の外側を半螺旋状に下行して行く.

以上のように内外縦走筋を剝離すると中輪筋のみが残 存するとととなる，中輪筋は頸部側方では，一部は縦走 の走向をとり, 一部は横走し, 又頸部腹側では一部は横 走し，一部は斜走して内尿道口部を半螺旋状にとり囲と んでいる. 頸部背側では，横走した筋束で内尿道口後縁 では厚い環状の箭層となっている。てれらの筋束のう ち，内尿道口の上縁扔よび両側縁では筋束は殆んぞ消失 し，頸部腹側掯よび雨側の筋束はそれぞれ前立腺へ移行 している. 頸部背側の筋束は, 内尿道口後縁で厚い筋肉 となり，てれが囲く前立腺底部に附着している。ての部 では中輪筋を前立腺から鈍的に剝離することは出来ず， 又内尿道口後縁の部で尿道長軸に直角に垂直断するとこ の部の筋層が内尿道口後縁を中心として環状に尿道下端 をとりまいているのを認める。

前立腺を精皁の高さで尿道長軸に垂直断すると，ての 筋肉は消失して, 既に筋束としては認められない, 前立 腺を尿道長軸に直角に数 $\mathrm{mm}$ の間隔で垂直断すると，乙 の筋層は内尿道口部より漸減して精阜に至って完全に消 失するのが認められる。

口） 40 才以上の 4 例 : 膀胱打よび尿道粘膜, 内外縦走 筋の走向状態はイ）と全く同様の所見であった。 ただ内 縦走筋を剝離すると，内尿道口の後縁中央を中心として 環状に中輪筋の隆起が，所謂 Annulus Urethralis とし て認められる，ただ中輸筋の前立腺底部との附着部は鈍
的に容易に缘離することが出来，中輪筋のつづきと考元 られる内尿道口後縁の筋肉の隆起, 即ち Annulus Urethralis は前立腺と一塊となって膀胱から剶離された。 この Annulus Urethralis を形成していた内括約筋は， 前立腺両側葉間で，尿道下面に接する明らかな筋束とし て認められた。前立腺を精阜の高さで尿道長軸に直角に 垂直断して, 近位端の前立腺の断面をみると, 程度の差 はあるが両側葉, 前葉, 中葉, 後葉がそれぞれ独立して みられ，乙の Annulus Urethralis を形成していた内括 約筋は両側葉下端の間に固く附着して居り (1 図), 更に 両側葉とその間を結ぶこの筋肉を一塊として他の葉加ら 容易に剥離出来る。そして Annulus Urethralis の突出 が明瞭に観察あれる ( 2 図).

これら 4 例は後に組織学的検索により明らかな腺腫形 成のあったものが 2 例, 残りの 2 例には一部に腺腫形成 を認めた。

ii) 手術例：摘出標本は，全て内括約筋部の検索を行な わんとしたため内尿道口後縁の部で膀胱の中輪筋と思わ れるものが腺腫に附着している ( 3 図). 先ず前立腺の前 連合を切断し, 前立腺と共に摘出された尿道粘膜を尿道 筋層と共に尿道長軸の方向に剝離除去し，次に附着して いる膀胼筋を鈍的に剝離すると前立腺底部で両側葉下端 に明らかな筋層が雨側葉を連絡しているのが認められる (4 図). 切断した前連合部を合わせると, 内尿道口後縁 部ではての筋層により明らかな隆起を形成し, Annulus Urethralis を作っていたものであるととが分かる.

この筋肉は, 前立腺底部の両側葉下端で, 雨側葉の側 方に迄至り, 一部は前立腺の内方に侵入し, 大部分は前 立腺の側葉に附着している.

c)小括

40 才以下 4 例, 40 才以上 4 例計 8 例の剖検例扣よび手 術摘出材料 21 例の内括約筋部を中心とした膀胱頸部から 前立腺への筋束の状態を総括してみると, 前立腺に腺腫 形成のない 40 才以下の 4 例では, 膀胱中輪筋の続きであ る内括約筋は明らかな筋層としては認めがたいが, 精阜 迄尿道後縁を中心として環状に続いている.

腺腫形成のあった 40 才以上の 4 例扔よび手術摘出材料 21例では，内尿道口後縁を中心とした中輸筋の連続であ る内括約筋は, 前立腺底部で Annulus Urethralis を形 成して膀胱に面し, 肥大した前立腺の両側葉下端を連結 してその側方で終り, 上方は所謂 Bell の筋肉に接して 尿道に面し，下方の一部は中葉に接し，一部は膀胱外縦 走筋をへだてて Denonvillier 被膜, 直腸前壁に面して 
第 1 困

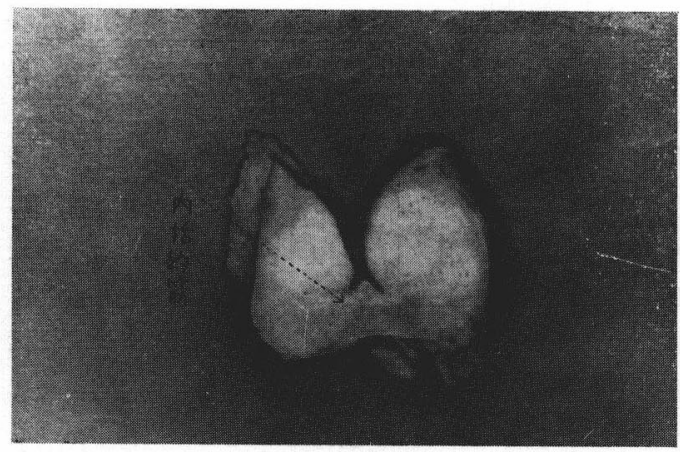

第 3 困

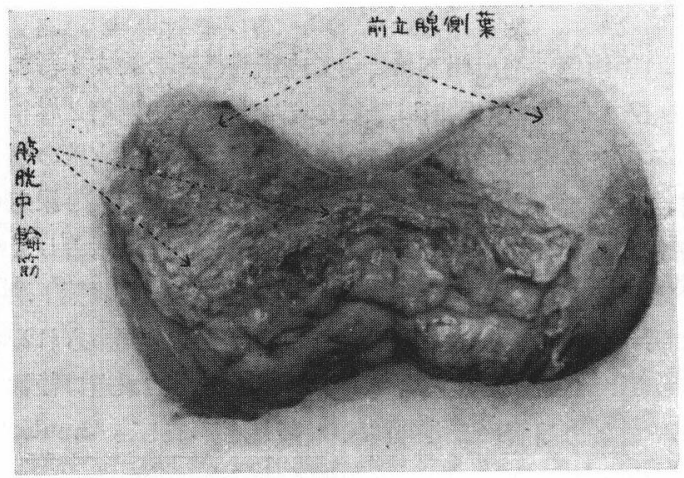

第 6 図

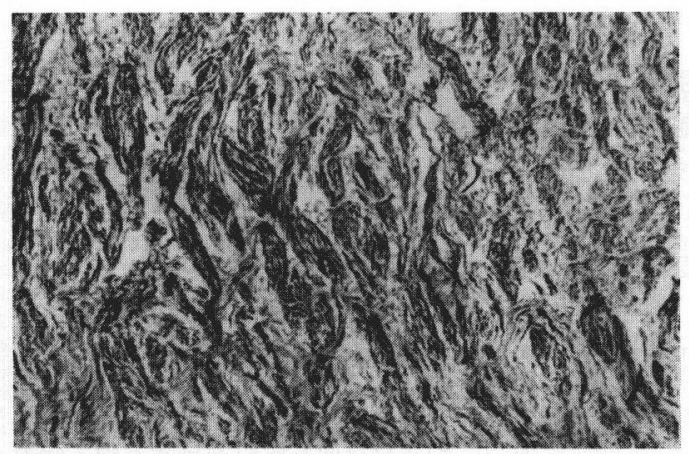

第 2 図

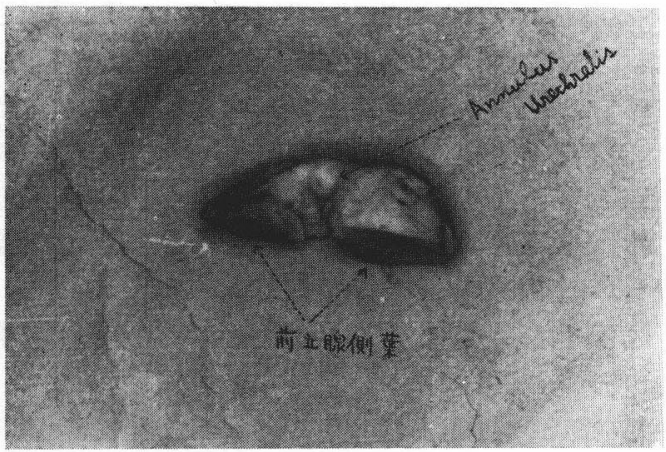

第 4 図

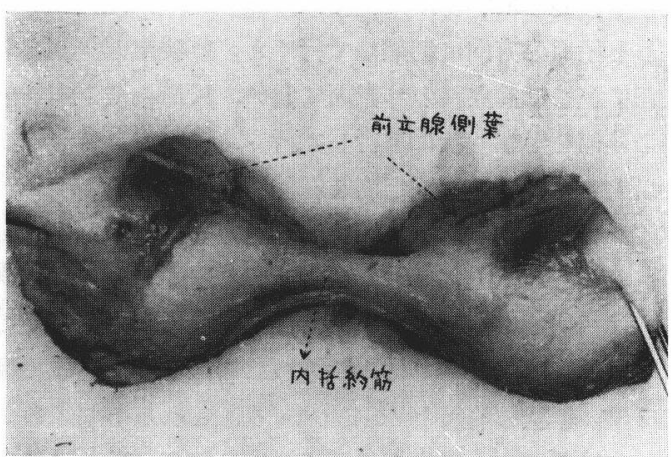

第 7 図

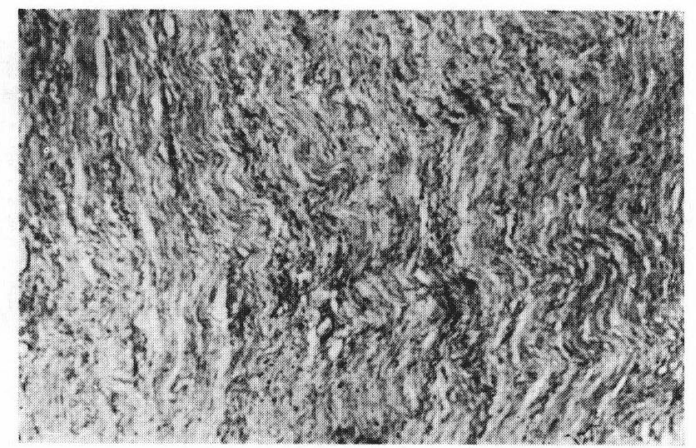


第 8 図

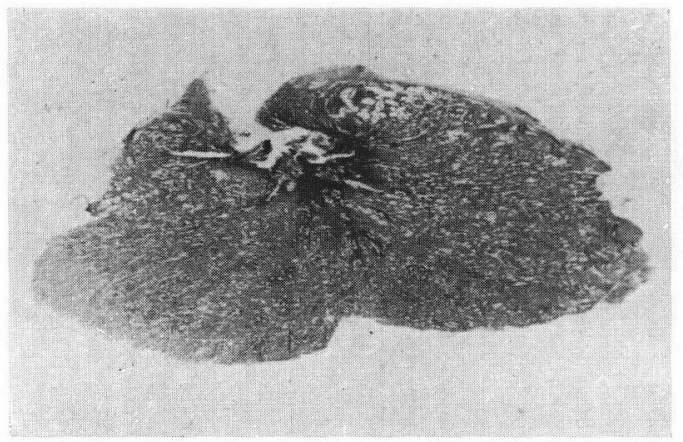

第10図

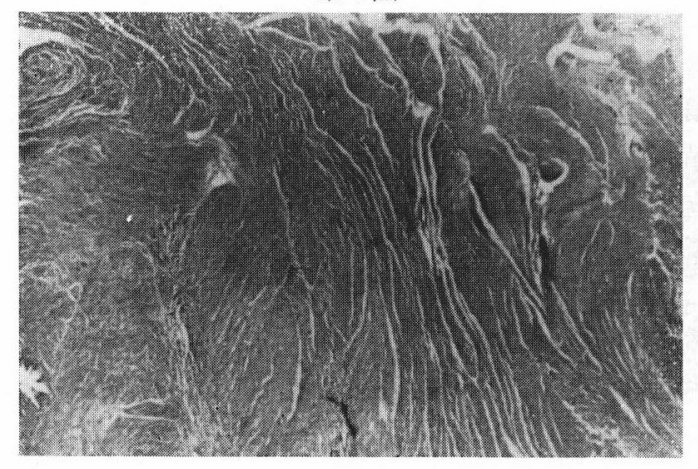

第12図

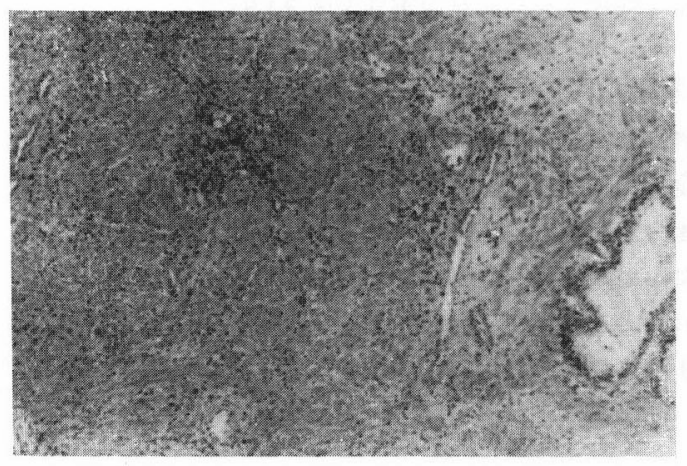

第 9 図

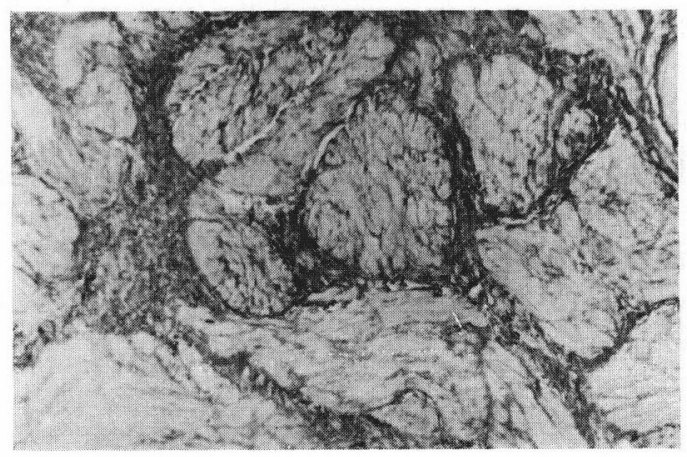

第11図

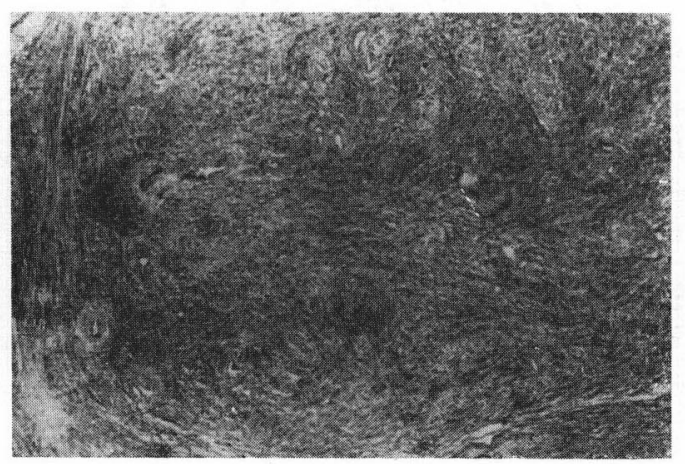

第13図

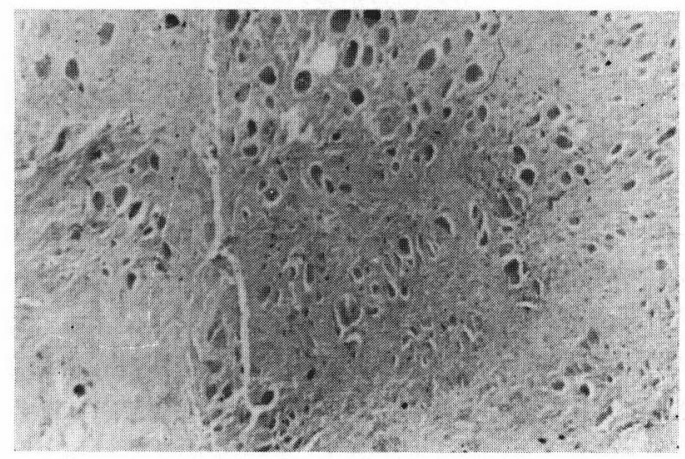


第14図

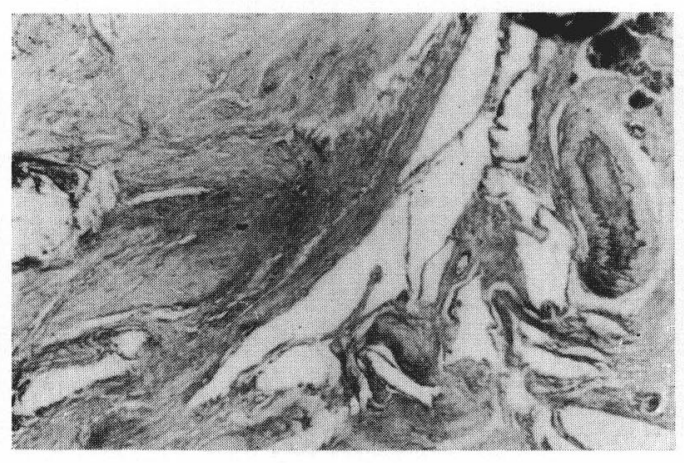

第 5 図

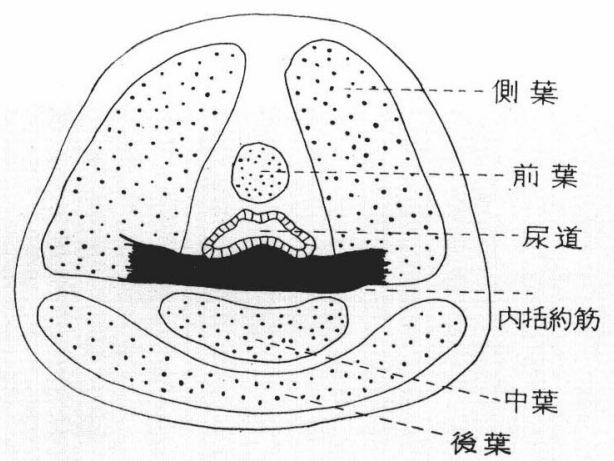

いる. 即ち, 従来膀胱内括約笠と考えられていたもの が，てれであろう( 5 図). 更に腺腫形成の認められた例 では, 内括約筋は前立腺と一塊となって膀胱筋層から容 易に剥離され，腺腫形成の一翼をになっている，てれら のととから内括約笳は, 膀胱の一部と考えるよりは前立 腺の一部であると考えた方が良いと思う。

B) 組織学的検索

a) 材料 : 肉眼的検索と同一条件の19日，12才，34才， 36才，42才，46才，55才，57才，63才，72才の計10例の 剖検例と頸部硬化症 23 例は打よび前立腺肥大症と診断し て手術したものの内, 頸部組織の充分摘出されているも の42例計65例を用いた。

b)方法扣よび成績

i)剖検例： 1 コの材料の半分を用い, 膀胱頸部から 前 立腺にかけて精阜の部迄, 尿道後壁の高さで尿道長軸に 水平沏断し, この水平断標本に就き検索し, 又40才以 下の 4 例では更に，材料の右半分を用いて縦断祭本を作 成し，それぞれへマトキシリン・エオシン，エラスチカ ワンギーソン，アザンマロリー染色を施して検索した。
第15図

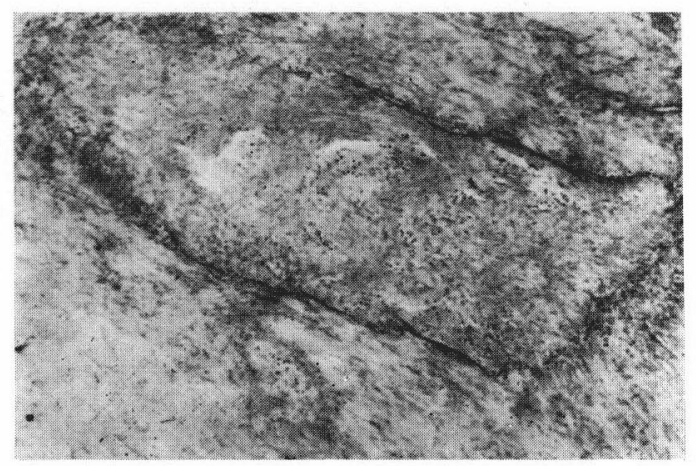

1） 40 才以下の 4 例 : 水平断標本では, 正常の膀胱粘 膜, 粘膜下層の下に第 1 の筋層が現われて米る ( 6 図). この筋層では, 各筋束は太く, 間質結合織は粗であり, 弾力線維は豊富にみられる. 第 2 , 第 3 の筋層は第 1 の 箭層につづいてみられるが，それぞれ筋束の性状，間質 結合織の状態は全く同様であり, 又弾力線維も豊富にみ られる，ただ筋層の方向がそれぞれの筋層により異なっ ているのみである.

てれに反して, 第 3 の筋層につづいて出現してくる内 括約筋と思われる筋層は, 特異で, 個々の筋束は概して 細く, 間質結合織は密に存する ( 7 図). そして特幑的な のは弾力線維を全く欠如することである。これにつづく 前立腺では，全く正常の前立腺組織をみる。

縦断標本では, 膀胱頸部で内括約筋は最も太く, 広く 存しているが，精阜に近づくにつれて漸減し，次第に前 立腺の間質内に細く大り込んで精皁の部では全く筋束と して捕捉するととは出来なくなる $(8$ 図).

口） 40 才以上の 6 例 : 膀胱壁の組織像は，亿）と全く 同様であるが，内括約筋では肥大增殖を認めたものが 2 例あり，他の例 4 はイ）と同所見である. 前立腺では, 全く正常の前立腺組織像を呈したものが 2 例, 程度と强 さの差はあるが，腺腔の拡大と腺胞の数の増加がみられ たもの 3 例, 間質の増殖の著明であったものが 1 例みら れた。 この他リンパ球, 形質細胞, 多核白血球の浸潤が 3 例にみられた。

ii)手術例 : 摘出材料 65 例につきi) と同様の染色を施 し，検索した。

1) 膀胼筋部 : 膀胱筋肉の附着していた 27 例中, 明ら かな筋線維の肥大と間質結合織の増殖を認めたものが 8 例 $(9$ 図), 小円形細胞の浸潤のあったものが 5 例, 膀胱 
筋の内括約筋に近接した部に強い fibrosis を示すもの が 3 例みられた。

口）内括約筋部：ての部の病変は次の 4 つた大別する ことが出来る。

1. a muscular hypertrophy type (10図)：肥大し た筋線維が mosaic 状に縦横に入り交ってい て，間質結合織の増殖は殆んどみられない。 myoma ともいう可き状態で，てれに近い像は 7 例みられたが，図の如き定型例は 4 例であっ た。

b . fibromuscular type (11図)：筋線維と間質結 合織が増加し，それぞれが mosaic 状に緹横に 入り交った状態である，前立腺肥大症の組織像 の一定型である線維筋性型と全く同一の所見を 呈するものである．乙の所見は muscular hypertrophy type の 7 例を除く他の全例にみら れているが，腺腫の侵入を伴わない fibromuscular type のみ認められたものは24例であっ た。

c . mixed type : 腺腫形成のみのものは 1 例もな く, 内括約筋部全体としては fibromuscular type の変化が強いが，両側葉に近い部の内括 約筋に腺腫を認めるもので，34例にみられた が，前立腺肥大症として手術したものに多かっ た。

2. inflammation (12図)：全例の約 $1 / 3$ 亿, 小円形細 胞が做蔓性或いは集簇性に浸潤している，肥大 した前立腺組織にみられるような lymphoid
様の所見はみられなかったが，内括約筋部のみ でなく，前立腺部にみられるものもあった。て の場合，細胞浸潤がどちらから先行したかは明 らかでない，浸潤細胞は，リンパ球を主と し，時に形質細胞がみられたが多核白血球は殆 んぞなく，巨細胞は全くみられず，梗塞像もな かった。

3. fibrosis(13図)：間質結合織の線維化が強くや や肥夫した筋束を島鴆状に取りまいているもの や，逆に変性して容積の減少した筋束を強い線 維化が取りまいているもの，更に筋束が間質結 合織により置きかえられたもの迄存する．小部 分の変化迄数えれば全例の約半数に認めらられ る変化である，てれらの病変には，小円形細胞 浸潤の伴うものと伴わないものとがあるが，後 者が線維化を示すものの約 $2 / 3$ である。

4. circulations insufficiency $(14,15$ 図) : 全例に, 血管硬化性病変が多少に拘らずみられることが 特徴的である。乙れには血管内膜の肥厚，endoarteritis obliterans, 一旦閉塞した血管が recanalisation したと考えられる像等が種々の程 度にみられる。

八）前立腺部：腺腫型が最も多く41例，混合型17例， 線維筋型 4 例，萎縮 3 例であった。

c)小括

剖検 10 例と手術摘出材料 65 例の組織像をまとめると, 表の如くになる。

\begin{tabular}{|c|c|c|c|c|c|}
\hline 部位 & muscular hypertropy & fibromuscular & adenomatous & mixed & atrophy \\
\hline 内括約筋 & 7 & 24 & 0 & 34 & 0 \\
\hline 前 立腺 & 0 & 4 & 41 & 17 & 3 \\
\hline
\end{tabular}

内括約筋部では， muscular hypertrophy type $の 7$ 例 老除き前立腺肥大症の一病型である fibromuscular type の像が全例にみられ，腚腫の形成が過半数に認められ た. 又 inflammation と fibrosis がほぼ半数に存し，血 管硬化性病変が大多数にみられている。乙れらの変化 は，内括約筋に隣接する膀胱打よび前立腺に認められる ものもあるが，ての場合何れが先行したかは明らかでな W:

\section{考按}

後部尿道，膀胱頸部に於ける尿路閉塞性疾患について は，古くから種々の議論があり，その取り扱う疾患の分 類，性状等にういても未だ統一的な見解がないようであ る.てれらのうち，膀胱頸部疾患のみについても同様 で，尚，新しい分類が提起されている ${ }^{10)}$. との原困の 1 つとして膀胱頸部の topography が明膫でないことをあ げることが出来る．膀胱頸部，殊に内括約筋の構造につ 
いては, 排尿運動と関連して膀胱筋, 尿道筋と共に多く の未解決の問題が残っている. 最近ではレ線学的探究 ${ }^{11}$ 〜15)が行なわれ,一方急速に増加した前立腺手術, 膀胱頸 部の手術等の術後尿失禁の問題とも関連して重視されて いる. この部の筋肉構造についての最近の優れた業跡に 小見山 ${ }^{16)}$ の研究がある。即ち，内括約筋を独立した筋肉 と記述せず，膀胱の内尿道口にある膀胱中輪筋に他なら ないとし, 中輪筋と外縦筋とが解剖学的に不可分の関係 にあるととから, 膀脳頸部と後部尿道との間に於ける極 めて短い部分の輪状筋層ではなく, 膀胱頸部から外尿道 括約筋に至る迄の後部尿道全体を指している. 筋肉構造 については井上 ${ }^{17)}$, Hunter ${ }^{18)}$ も同様な記載をしている. 落合は ${ }^{19)}$, 利尿筋は内尿道口部に近づくと比較的明瞭な 2 層に分かれ，一つは外縦走の肥厚した筋層で尿道の後 外側汃前立腺前面に向って斜走して馬蹄形を形成し， 他は内層の輪状走行の筋で内側を更に下行し, 精丘に達 しててで第 2 の馬蹄形を形成している. 即ち, 内括約筋 は完全な輸状を形成するものでなく，アーチ型の筋層で あり，後部尿道全体が括約筋的な働きをなすという。

小見山，落合共に後部尿道全体が内括約筋的働きをす るというととでは，軌を一つにしている．ての内括約筋 が輪状でなく背側があいている環状であるとてろから， Waldeyer は Annulus Urethralis と呼んでいる. 又 Wesson ${ }^{20)}$ は 膀胱背部縦走筋の一部を内尿道口附近に 認 め, これを膀胼の括約筋作用に関与するものであろうと し, Young \& Wesson ${ }^{21)}$ は vesical orifice には $2 つ の$ component, 即ち vesical orifice を上にあげ, pursestrings fashion にとぢる筋肉ともう1つは所謂 Bell の筋 肉で interureteric bar から精阜に迄拡がる筋肉だとい う.

Van Duzen \& Duncan ${ }^{22)}$ も, 膀胱筋層と前立腺尿道 とは連続的であると考えている. 何れにしろ内括約筋は 従来考光られていたように輪状のものでなく, 又内括約 筋は独立した筋肉でもなく，後部尿道全体が括約筋的な 働きをしているようである。ただ田林 ${ }^{22}$ が述べているよ うに臨床上では明らかに所謂内，外括約筋があり，内括 約筋は膀胱と尿道を境し，外括約筋は前部扔よび後部尿 道を区別している．われわれはてれを臨床上に利用して 診断，治療に応用しているのである，そうすると，後部 尿道全体が括約筋的な働きをしてはいるが，臨床的に内 括約筋と考元られるものは, 当然これは従来考元られて いたように内尿道口後縁で肥厚している膀腅中輪筋であ ろう. そしてての内括約筋は解剖学的には膀腅中輪筋の
連続であるが，機能的には膀胱に所属しているのか，又 は膀胱に最も近い後部尿道の部分, 即ち前立腺に所属し ているのかという問題になる. 元来前立腺は膀腅のVorstehende Drüse と考光られて於り，Van Duzen \& Duncan も前立腺は膀胱頸部の腺構造に過ぎないとい い, 又, 膀胱壁と前立腺は連続性で両者の間に線維性の 隔壁がないととは認められている。乙れらから内括約筋 が膀胱と前立腺の何れ偊しているかを明らか比するて

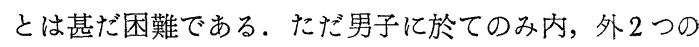
括約筋があるのに，女子では 1 つの括約筋しか存しない こと, 男子では外括約筋が健全であれば，内括約筋の状 態の如何にかかわらず尿失禁を来たすととがないという 事実よりすれば，内括約筋の機能として考元られるの は，排尿の control と共に射精との関係である. Henning ${ }^{24)}$ によれば， uvula vesicae は男子にしかなく，精 液の膀胱への流入を防ぐ役割をしているという。とれと 同様な働きを内括約筋が行って居り，同時に射精㭙に尿 が精液と一緒に流出するのを防いでいるのではあるまい 汃，てのように考光てくると機能的には内括約筋は全く 性器, 即ち前立腺に属さしむ可きであろう.

われわれは, 前立腺肥大症に於ける内括約筋の形態学 的観察から，内括約筋は前立腺に所属せしむ可きである と考えたが，正常前立腺に於ける内括約筋も上述の機能 的困子扣よび肥大症のときの内括約筋の形態, 構造から 帰納して前立腺に所属せしむ可きと考える.

われわれは，正常と思われる剖検材料に於て膀胱頸部 汃ら前立腺迄，尿道長軸に対して水平断標本を作製して 検索したが，乙れは縱断標本では膀胼筋層と内括約筋と が判然と区別出来ないからである．同様なととを四ッ柳 25)も認めて居り，縱断標本では輪状筋層も斜走筋層も完 全に同様な断面を示す故，括約筋を弁別し得ず，寧ろ筋 層の大部分が輪状筋, 即ち括約筋の断面と誤認せられる という.

ただ縦断標本でみると内括約筋が，尿道の遠位端のど の部迄及んでいるのかを知るてとが出来るが，われわの 検索では精阜迄筋束として認められたものはなく，てれ も四ッ柳の記載とほぼ一致した。

組織学的に正常の膀胱筋層と内括約筋とは明らかな相 違があり, 手術摘出材料が内括約筋か, 或いは膀胼筋層 なのかの判定基準ともなり, 重要である. 手術的にての 内括約筋を完全に剔出するときには，膀胱と尿道の連絡 は薄い外縦走筋の連続のみのつながりとなり，内括約筋 が囲く周囲と癒合している場合には，殆んど切断される 
ととになる. Vondra et $\mathrm{al}^{26)}$ も完全な内括約筋の剔出 は，膀胱頸部の穿孔を意味すると述べている．われわれ もとの内括約筋を剔出する際, 精囊, 精管を 1 例, 精管 のみを 2 例同時に剔出した経験を有している．てれらの 例でも既に発表した前立腺剔出腔の縫合法27),28) により 何らの障害も来たしていない，手術摘出標本に於ける内 括約筋の組織像は，前述のように内括約筋を前立腺の一 部と考えると甚だ興味深い，即ちほぼ全例に線維筋性の 増殖をみているのであって，前立腺部の組織像が腺型が 多く, 線維筋性型の少ないととと比較すると大いに異る.

Albarran-Hallé による腺性, 線維筋性, 混合性肥大の $3 つ の$ 分類については，ただ部位的に腺腫が，或いは線 維筋腫が優勢であるだけで，殆んど全ての前立腺肥大症 に両方の所見のみられるてとからての分類法に賛成しな い人もあり，最近でも菅野・加藤29) は全て混合型である と述べているが，乙てでは現在多くの人に支持されてい る Albarran-Hallé の分類に従った.

前立腺肥大症の完成されたものは，大部分が腺構造を 䒬しているが，発生病理上の始めの変化は腺性の病変で はなく，間質の増生であり，てれに続発して腺上皮の増 生が加わってくるとされている ${ }^{30), 311 . ~}$

前立腺肥大症に於ける病変が腺組織のない内括約筋に のみ生じたときには，線維筋性型のみに終始することに なるのであろう。

前立腺肥大症と膀胱頸部疾患との関係については，腺 腫が大きければ問題はないが，所謂 miniaturform のと きには膀腅頸部疾患との異同が問題となる。てれについ ては古くから議論があるが，てれを概括した落合ら ${ }^{32} の$ 詳細な文献的考察が，乙の間の事情を充分説明してい る. この中で落合らは排尿障害を起てすには腺腫を重視 し，小結節のみでは排尿困難を来たさず，線維腫扔よび 筋腫のままで排尿困難を起てすには相当の大きさである てとを要すると推論している，之に反して土屋は ${ }^{10)}$, 括 約筋硬化症中に腺腫像は認められても腺腫によって括約 筋が緊張を増し，排尿困難を起てしているとは考えられ ず，頸部組織は筋組織と結合織のみで腺腫をかいて硬化 性変化を示すものがあるてと，又，腺組織はあっても萎 縮性でてれによって頸部の緊張が堌していると考えられ ないし，腺腫合併例に於ても凡てに於て排尿困難は内尿 道口部に於ける一次的の線維化によって異常に弾力性が 失われているためで, 腺腫そのものはさほど排尿困難に 与ってはいないという。

われわれの観察では，内括約筋が線維筋性の増生を示
して腺腫形成のみられなかったもの, 又, 前立腺に腺腫 があって線維筋性の増生の明らかでないものの両者共に 排尿困難を認めているので, 線維筋腫も腺腫もその位置 と大きさの関係で排尿困難を起しし得ると思う.

元来, 前立腺症を呈するが前立腺の腫大を伴わない疾 患を総称して膀胱頸部疾患と呼んでいるが，機能的なも のは除き，器質的障害に限定されているようである ${ }^{33) ，}$ 10). 前述のように内括約筋を前立腺の一部と考えると， ての内括約筋にのみ線維筋性の腫大を生じても臨床上前 立腺の腫大としては認められず，膀脂頸部疾患に数えら れやすいが，前立腺々腫の矮少型が前立線肥大症に入れ られるように内括約筋に生じた線維筋性型の病変も前立 腺肥大症の範疇に入れらる可きである.

ただての線維筋性型の病変の他に, 炎症, 線維化, 循 環不全等の組織像を多数にみているてとから，前立腺肥 大症の他に，その他の原困によって起った内括約筋部の 病変, 例光ば Bodian ${ }^{34)}$ が, 乳幼児にみた fibro-elastosis のような病変の存在は否定出来ない。

\section{結 論}

1. 剖検材料 8 例と手術摘出材料 21 例につき，内括約 筋部を中心として膀胱頸部から前立腺部迄の筋束の状態 を肉眼的に観察した結果，内括約筋は膀胱の一部と考元 るよりは，前立腺の一部と考えた方が良い。

2. 剖検材料 10 例と手術摘出材料65例につき，内括約 筋部を中心として膀胱頸部から前立腺部迄の組織学的検 索を行なった結果，病変例に於ては，内括約筋部の組織 像として 1. muscular hypertrophy type, 2. fibromuscular type, 3. mixed type の 3 型が認められた.

3. 40才以上の男子の idiopathic bladder neck contractur と考元られたものの大部分は，前立肥大症の線 維筋性型, 即ち前立腺肥大症そのものであると考光る。

御指導と御校閲を賜った恩師永田正夫教授に感謝の意 を表し, 御教示頂いた横浜医大病理学教室阪井敏治教授 に篤く御礼申し上げます. (本論文要旨は昭和 38 年 11 月 21 日，第278回日本泌尿器科学会東京地方会で発表した)

\section{文献}

1）市川篤二：日泌尿会誌，54，953，1963.

2）辻一郎，斯波光生 : 綜合臨床，4，44I，1955.

3）辻一郎 : 小児泌尿器科の臨床, 金原出版, 東京, 1962.

4）市川篤二・他：日泌尿会誌，49，109，1958.

5）宮坂哲：臨床皮泌，10，1027，1956.

6）小西武彦: 臨床皮泌，12，353，1960.

7）伊藤文俊：皮と泌，22，573，1960. 
8）大熊博雄, 水本龍助 : 小览科, 2, 99, 1961 .

9）土屋文雄：日本医事新報，872，1988，1939.

10）土屋文雄：日泌尿会誌，54，659，1963.

11）大島浩太郎：日泌尿会誌，53，65，1962.

12）浜屋修：日泌尿会誌，54，37，1963.

13）岡直友 : 泌尿紀要, 3, 3, 1957.

14）柳瀬功一：日泌尿会誌，52，1078，1961.

15）高安久雄他：日泌尿会誌，45，159，1954.

16）小見山茂入：日泌尿会誌，49,821，1958.

17）井上彦八郎：日泌尿会誌，43，332，1952.

18) Hunter, E. T. : J. Urol., 71, 695, 1954.

19）落合京一郎：臨床皮泌，9，1218，1955.

20) Wesson, M. B. : J. Urol., 9, 279, 1920.

21) Young, H. H. \& Wesson, M. B. : Arch. Surg., 3, 1, 1921.

22) Van Duzen, R. E. \& Duncan, I. G. : J. A. M. A. : 153, 1345 . 1953.
23）田林綱太 : 日本泌尿器科全書, 5 巻, 303 , 金 原出版, 東京, 1960.

24) Henning, O. : Zschr. Urol.,50, 680, 1943.

25）四ツ柳正造：日泌㽷会誌，26，473，1937.

26) Vondra, N. et al : Urol. int., 15, 212, 1963.

27）水本龍助 : 手術, 17, 560, 1963.

28）水本龍助他: 手術, 18, 203, 1964.

29）菅野英男，加藤一也：名市大医誌，11，1003, 1961.

30) Moore, R. A. : J. Urol., 50, 680, 1943.

31) Demming, C. L. \& Woff, J. S. : J. Urol., 42, 566, 1939.

32）落合京一郎・他. 日泌尿会誌，36，423，1944,

33）近藤厚 : 臨床, 泌, 9, 109, 1955.

34) Bodian, M. : Brit. J. Urol., 29, 393, 1957. （昭和39年 1 月 17 日受付，特別揭載） 